\title{
Micropropagation of Leuce-poplars and evaluation of their development under sandy site conditions in Hungary
}

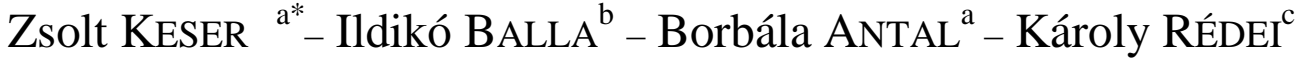 \\ ${ }^{a}$ National Agricultural Research and Innovation Centre, \\ Forest Research Institute, Püspökladány, Hungary \\ ${ }^{\mathrm{b}}$ National Agricultural Research and Innovation Centre, \\ HHPM Non-profit Ltd., Budapest, Hungary \\ ${ }^{\mathrm{c}}$ National Agricultural Research and Innovation Centre, \\ FRI \&HHPM Non-profit Ltd., Sárvár-Budapest, Hungary
}

\begin{abstract}
Leuce-poplars are a native stand-forming tree species throughout Hungary. Several species or selections of them are used as ornamental plants in parks or to line streets and highways. They cover approximately 4.0 per cent of the total forested area in Hungary (70 000 ha). The white (grey) poplar belongs to the Leuce poplars and plays a significant role in sand fixation, regional forestation, and nature conservation. The National Agricultural Research and Innovation Centre, Forest Research Institute or NARIC-FRI (formerly known as the Forest Research Institute) is involved in long-term breeding work for the selection of fast-growing white poplar trees under dry conditions. In vitro multiplication of trees is applied mainly to fruit growing trees in Hungary; in forestry research it is used primarily for selective breeding. This paper presents a short overview of the most important issues concerning the biotechnology of different Populus species, the related research on micropropagation trials, and the results of field investigations of micropropagated Leuce-poplar clone experiments.
\end{abstract}

\section{Populus sp. / biotechnology / in vitro / rejuvenation / selected clones / field trials}

Kivonat - Leuce-nyárak mikroszaporítása és homokterületen történ termesztésük kiértékelése Magyarországon. A Leuce-nyárak shonos állományalkotó fafajok Magyarországon. Néhány fajukat, illetve szelekciójukat parkokban, utcák, utak mentén díszfaként használják. Magyarországon az összes erd sült területnek kevesebb mint 4\%-át teszik ki (70000 ha). A Leuce-nyárakhoz tartozó fehér (szürke) nyár jelent s szerepet játszik a homoktalajok megkötésében, azok erd sítésében, és természetvédelmi szempontból is fontos. Száraz term helyi viszonyokra szelektált, gyorsan növ Leuce-nyárak hosszútávú nemesítési munkája folyik a korábban Erdészeti Tudományos Intézet, ma már a Nemzeti Agrárkutatási és Innovációs Központ Erdészeti Tudományos Intézetében (NAIKERTI). Magyarországon fás növények esetében in vitro szaporítási eljárásokat $\mathrm{f}$ leg a gyümölcstermesztésben alkalmaznak, az erdészeti kutatásban els sorban a szelekciós nemesítés során használják. Jelen tanulmány rövid áttekintést nyújt a különböz nyár fajok legfontosabb biotechnológiai vonatkozásairól, a kapcsolódó mikroszaporítási kísérletekr 1, valamint mikroszaporítással el állított Leuce-nyár klónok termesztési kísérleteinek eredményeir 1.

Populus sp. / biotechnológia /in vitro /rejuvenilizáció / szelektált klónok / terepi kísérletek

\footnotetext{
*Corresponding author: keseruzs@erti.hu; H-4150 PÜSPÖKLADÁNY, Farkassziget 3.
} 


\section{INTRODUCTION}

Inside the section of Leuce poplars, the white poplar (Populus alba L.), and its most important natural hybrid the grey poplar, (Populus $\times$ canescens) are native to Hungary. The area of native poplar stands and plantations was about 77000 ha in 2012 (4.0 per cent of the total forested land), with a standing volume of 13.0 million $\mathrm{m}^{3}\left(169 \mathrm{~m}^{3} \mathrm{ha}^{-1}\right)$.

The NARIC Forest Research Institute is the most important national institution for poplar breeding and improvement. Investigations of selected individuals and populations of native poplars laid the foundation for their in situ and ex situ conservation.

Clonal selection is very effective on additive and non-additive genetic components. Asexual propagation is extremely important for the conservation of selected genotypes. Traditional vegetative propagation methods, like root cuttings and greenwood cuttings, are acutely limited, especially at the beginning of the production. The role of micropropagation can be important at this stage. This was started in the previous Research Institute for Fruitgrowing and Ornamentals in Budapest, which is now known as the NARIC Fruitculture Research Institute.

Poplars were one of the first objectives of in vitro propagation trials (Gautheret 1934, Mathes 1964, Winton 1968, 1970, 1971, Wolter 1968, Chalupa 1974). Cambial tissues were used as basic material in these experiments. First callus improvement, then shoot or root development was induced on the callus surface. Sometimes it occurred without any outside effect. The connection between the regenerated shoots and roots was occasionally unclear. The collected opinions founded the vegetative propagation established from a single bud and different originated callus based plant regeneration (Noh - Minocha 1986).

Whitehead and Giles (1977), Christie (1978), and Ahuja (1983, 1984) micropropagated sterile bud originated plantlets of poplars for the first time. Difficulties of culture establishment and genetically determined differences between the species were pointed out in the presentation of their results. Success of establishment also depends on the age of the mother plants.

Development of micropropagation methods of poplars for commercial purposes was the aim Barocka et al. (1985). Medium optimisation was continued by Chun et al. (1986). Wann et al. (1988) improved the micropropagation method of the tetraploid clone ' $\mathrm{Ta}-10$ ' for the substitution of vegetative propagation by grafting. Development of the micropropagation procedure for different poplar species/clones continues today. Coleman - Ernst 1990, IordanCostache et al. 1995, Zhang et al. 2000, Noël et al. 2002, Phan et al. 2004, Kang et al. 2009, Thakur et al. 2012 summarised the multiplication procedure of several poplar species that were inoculated or not inoculated with ectomycorrhizal fungus for different experimental purposes.

As the use of micropropagated plantlets became more and more popular, questions of genetic uniformity arose. Rahman - Rajora (2001) used microsatellite analysis to examine a phenotypic homogenous population of Populus tremuloides originated from a single mother plant produced by micropropagation. No difference could be detected in 8 out of 10 loci, but differences were observed in the cases of 2 loci. These results offer the possibility of genetic modification during the micropropagation procedure, without any phenotypic change. Genetic uniformity of the traditional methods of propagated plants (grafting, cuttings) was not controlled in the same time.

Breeding work based on in vitro explants started almost parallel with the development of an in vitro mass-propagation procedure for poplars. Protoplast and cell suspension production followed by plant regeneration were the aims of Douglas's (1982) and Ahuja's (1983) research work. Savka et al. (1985) improved the efficacy of breeding methods with early stage embryo isolation and nurturing under in vitro conditions. In the nineties, regeneration trials 
for breeding purposes began (Son - Hall 1990, Altman 2003, Confalonieri et al. 2003, Häggman et al. 2007, Yadav et al. 2009, Maheshwari - Kovalchuk 2011) followed with publications on agrobacterium mediated transformation (McCown et al. 1991, Leplé et al. 1992, Song et al. 2006, Nishiguchi et al. 2006).

White poplar selected clones were micropropagated in the laboratory of NARIC Fruitculture RI in collaboration with the NARIC Forest RI. Plant tissue culture methods provide us with new means to speed up the vegetative propagation of selected clones and give us the opportunity to establish new clone experiments and seed orchards (Rédei - Balla 2007).

\section{MATERIALS AND METHODS}

\subsection{Plant material for micropropagation trials}

All the clones/cultivars originated from the clone collection of NARIC Forest RI:

Populus alba clones, number: 101 . 'H 337' ( $P$. alba $\times P$. grandidentata),

103. 'H 384' ( $P$. alba $\times$ P. grandidentata $)$,

109. 'H 425-4/1' (P. alba $\times$ P. alba),

111. 'H 425-4' (P. alba $\times$ P. alba),

112. ' $K-1$ ' Populus hupehensis and

114. 'K-2'Populus alba originated from China.

\section{Plant material and growing site for the field evaluation}

In the clone trial, clone 101 ' $H$ 337' $(P$. alba $\times P$. grandidentata $), 103$ 'H 384' $(P$. alba $\times P$. grandidentata), 104 ' $H$ 325' $(P$. alba $\times P$. grandidentata $)$ and 111 ' $H$ 425-4' $(P$. alba $\times$ $P$. alba) and Populus $\times$ canescens seedlings can be found as controls. The experiment was set up in the spring of 2004 with one-year-old micropropagated plants (for the clones) and oneyear-old seedlings (for the control). A randomised block system with three replications was used. The initial spacing was $2.5 \times 2.0 \mathrm{~m}$. In every replication, 30 plants were planted. The total experimental area was $0.43 \mathrm{ha}$. The one-year-old seedlings were produced by the Kiskunsági Forestry Joint Stock Company.

The experiment itself was allocated in subcompartment Kecskemét 40A in the Danube Tisza interflow region (in central Hungary). The main ecological characteristics of the studied area are: forest steppe climate zone; humidity of the air is less than $50 \%$ in July at 2 pm; during the period at the test area the annual precipitation is between $263.8-560.3 \mathrm{~mm}$; hydrology: free draining; genetic soil type: humid sandy soil with very shallow rootable depth. The latitude and longitude coordinates of the experimental area are $N$ 46.883547, E 19.588868.

\subsection{Micropropagation}

Micropropagation is a useful method for breeders, because a large quantity of uniform plants can be produced in a short time from a single tree or bud.

Steps of the micropropagation method:

1. Establishment of sterile in vitro culture

2. Improvement of multiplication procedure in a growth - room of $22{ }^{\circ} \mathrm{C}, 1500 \mathrm{Lux}$ light intensity and 16/8 photoperiod.

3. Development of rooting

4. Acclimatization to greenhouse conditions

5. Adaptation under field conditions

6. Plantation 


\subsection{Field evaluation}

\section{Tree classification on the field}

Characterization of stem quality, including their health condition, was defined by using the following stem quality classes:

Class 1 - The stem is straight, cylindrical, healthy and reaching the top of the crown. Crooks are tolerated in one dimension only, up to a bend of less than twice the stem diameter. The lower two-third of the bole is free of live branches.

Class 2 - The stem is straight and healthy, forks are tolerated, but only if they are in the uppermost third of the tree. Crooks are tolerated in one dimension only, up to less than 4 times the stem diameter.

Class 3 - The stem is crooked, leaning and more or less damaged. Crooks may reach 6 times the stem diameter in one dimension and minor crookedness in a second dimension is tolerated.

Class 4 - The stem is very crooked in more than one dimension and heavily damaged. Low branching, forked trees sometimes with broken crown.

The stem quality index was estimated by the arithmetic average of the stem quality classes.

\section{DESCRIPTION OF THE METHOD USED AND DEVELOPED FOR MICROPROPAGATION}

\subsection{Establishment of sterile culture}

Three different explants were used for the establishment of a sterile culture of poplar clones:

1. Winter buds were collected in February. After a preliminary disinfection, buds were forced flushing in a thermostat with high relative humidity under artificial light. Shoots developed under controlled conditions were disinfected and planted into growing medium.

This method was found to be successful by disinfection in the case of white poplar. Most of the shoots became sterile, but they stopped growing under in vitro conditions and died after a short time.

2. Shoots developing in springtime, following a careful disinfection, grow quickly.

3. Woody cuttings are not sensitive for disinfection, but often stop further development under in vitro conditions.

Actively growing shoot-tips of a young tree are suitable for culture establishment. In the case of breeding, when the mother plants are about 30 years old or older, the yearly growth is usually only a few millimetres. The early closing buds begin to grow only after a long rejuvenation period.

\subsection{Rejuvenation}

Rejuvenation can be carried out under 1) in vivo or 2) in vitro conditions.

1) In vivo rejuvenation means involving horticultural methods into the procedure of establishment:

- Rooted cuttings originated from the selected mother tree are grown in a greenhouse (Figure 1), with regular plant protection, they are prepared for the establishment (P. alba clones number: '109' and '111').

- Graftings are used as explants ( $\mathrm{P} \times$ euramericana cv. 'Kopecky').

In vivo rejuvenation is difficult, because any kind of traditional vegetative propagation with adult trees is hard work. 


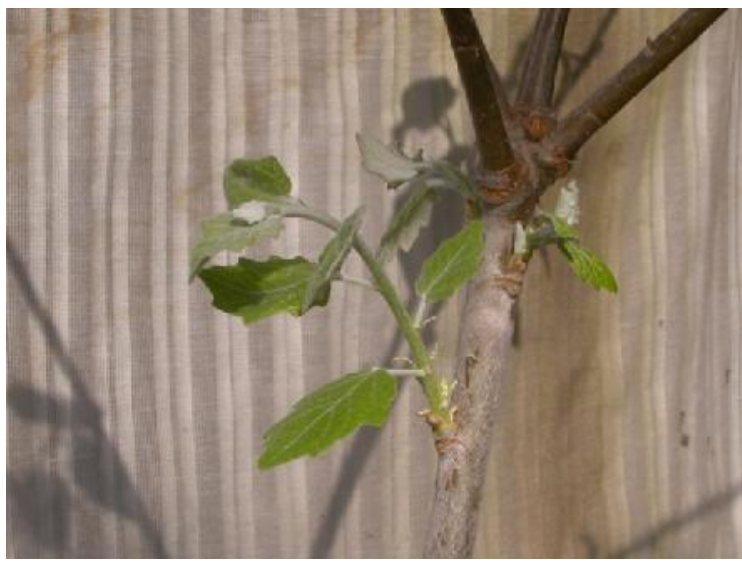

Figure 1. Forced flushing of Leuce-poplars for in vitro establishment

2) Rejuvenation in vitro means that the sterile cultures are transferred to fresh medium daily at the beginning, later weekly as far as the fenolic compounds differ into the medium and decrease their inhibition for development (Figure 2). Growth regulators induce flushing at the same time ( $P$. alba clones number 101, 103, 112, 114).

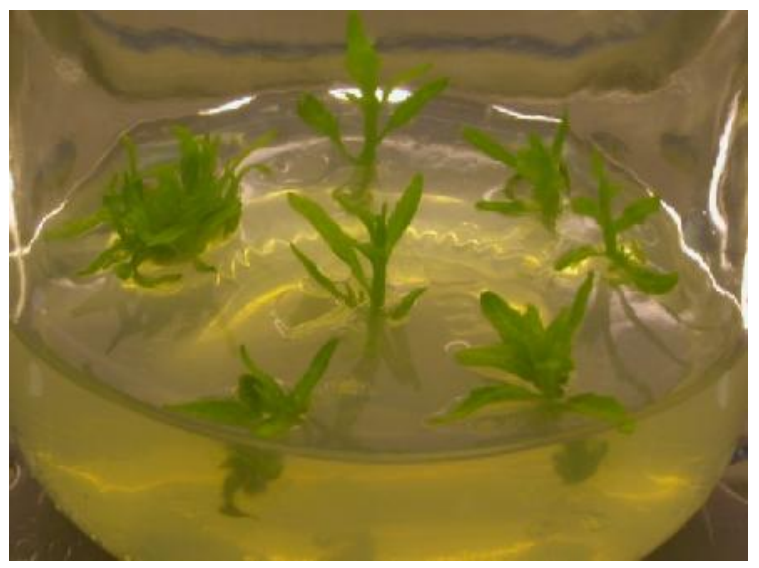

Figure 2. The sterile cultures start to grow

\subsection{Multiplication}

Experiments for propagation under in vitro condition start when enough sterile culture is prepared. All the cultures are grown in a culture room under controlled conditions: $22{ }^{\circ} \mathrm{C}$, 16/8 day/night photoperiod, 1500 Lux warm white light intensity.

Medium experiments are based on MS (Murashige - Skoog 1962) and WPM (Lloyd McCown 1980). Poplar shoots are very sensitive to the nitrogen form and concentration as well as for the added growth regulators. They have to be determined clone by clone.

The multiplication rate is typical for the species, clones/cultivars. With poplars, 5-8 new shoots develop monthly. The typical propagation rate can be detected 3 to 5 months following establishment when the cultures were adapted to the in vitro conditions. The developed new shoots isolated from the mother plants are the base of the next propagation phase. The multiplication phase has to be repeated till the required shoot number for rooting is produced. The shoots growing on the propagation medium are elongated and suitable for rooting (Figure 3-4). 

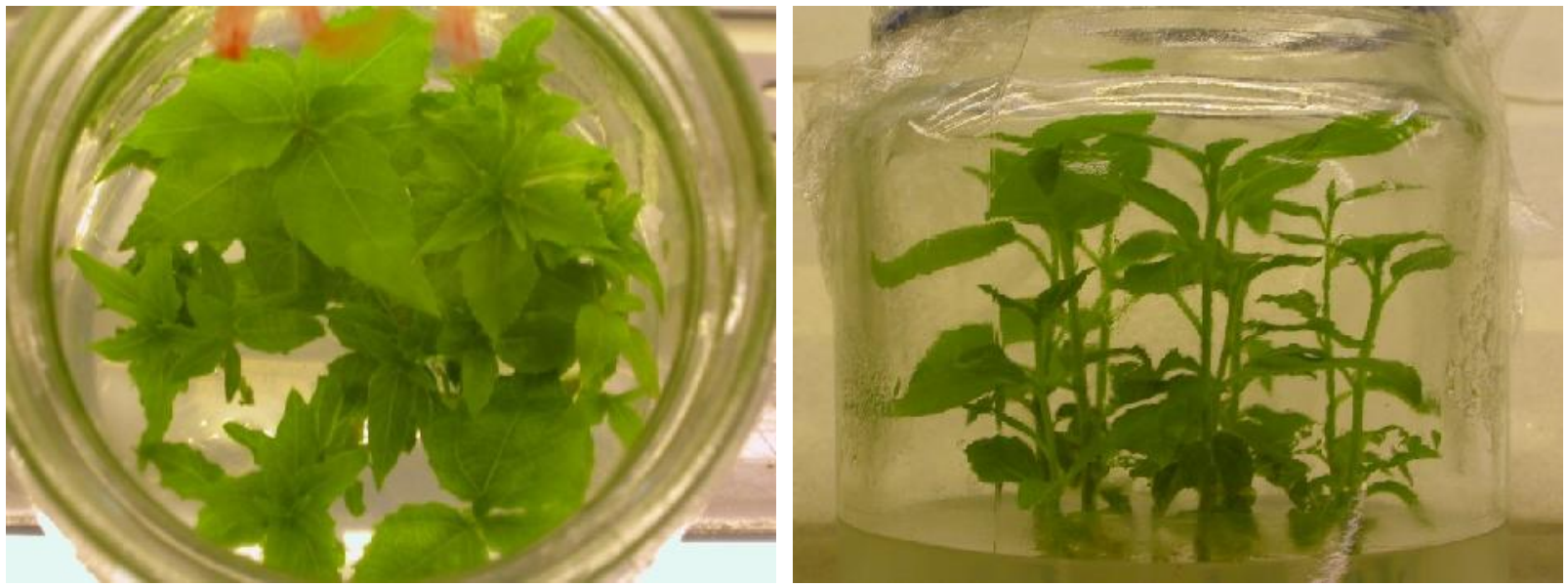

Figure 3-4. Leuce-poplars in the propagation phase

Vitrification often occurs in white poplar cultures causing a depression of the multiplication rate. Keeping the concentration of major and minor elements as well as growth regulators at a low level can help the cultures avoid these plant-physiological abnormalities. The vitrified cultures have to be eliminated.

\subsection{Rooting}

Spring time, from February until May, is the best period for root induction.

15-20 mm high, 3-week-old shoots can be rooted in half-strength major and minor elements, reduced sugar containing medium supplemented with a low concentration of auxine.

Rooting rate of $P$. alba clones is about 80-90 percent (Figure 5-6), $P \times$ euramericana $\mathrm{cv}$. 'Kopecky' about 60 percent.
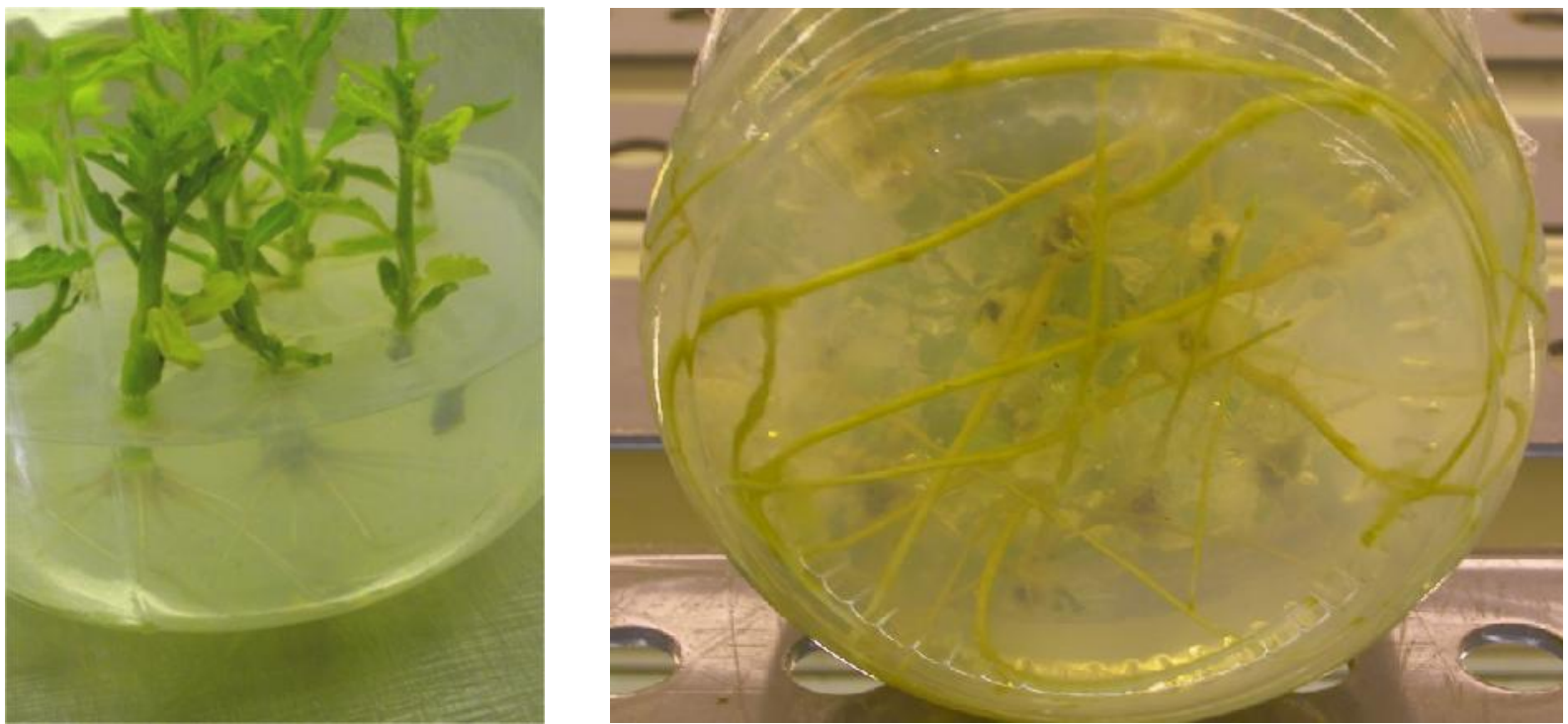

Figure 5-6. Rooted Leuce-poplars in vitro

During weeks 3-4, the roots develop and growth of the plantlets achieves the size appropriate for acclimatization (Figure 7). 


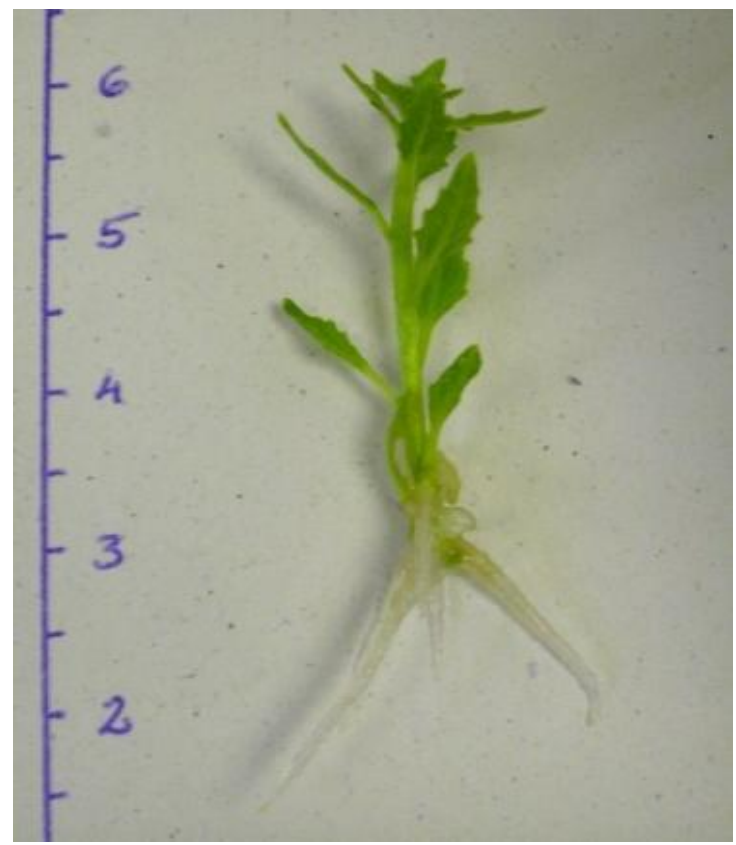

Figure 7. Rooted poplar plantlets ready for acclimatization

\subsection{Acclimatization}

Acclimatization means the period (4-6 weeks) where the plantlets - developed under sterile conditions - are adapted to semi-sterile greenhouse conditions. This is one of the most difficult parts of the micropropagation procedure. Spring is the best time for acclimatization, because days grow longer and the greenhouse temperature can be kept between $15-30{ }^{\circ} \mathrm{C}$.

The quality of the substrate has to be chosen to fit the requirement of the plant species. With trees, usually fibre, - reach substrate with high water capacity and a $\mathrm{pH}$ of about 6-6.5 can be used. Nutrition can be contained in the substrate or can be added together with the water supply.

Following the transplantation of plantlets into the substrate, a relative humidity of $90-95 \%$ has to be ensured for them until the stomas begin to work and the development of plant skin is finished (about 10 days). After then the relative humidity can be reduced to the normal greenhouse level. Protection against direct sunlight is also important during the whole procedure.

Attention must be paid to plant protection, mainly against fungal infection. By the end of the acclimatization, the plantlets grow up to $15-20 \mathrm{~cm}$ (Figure 8), which is a good size for transplantation under shaded and irrigated nursery conditions (Figure 9).

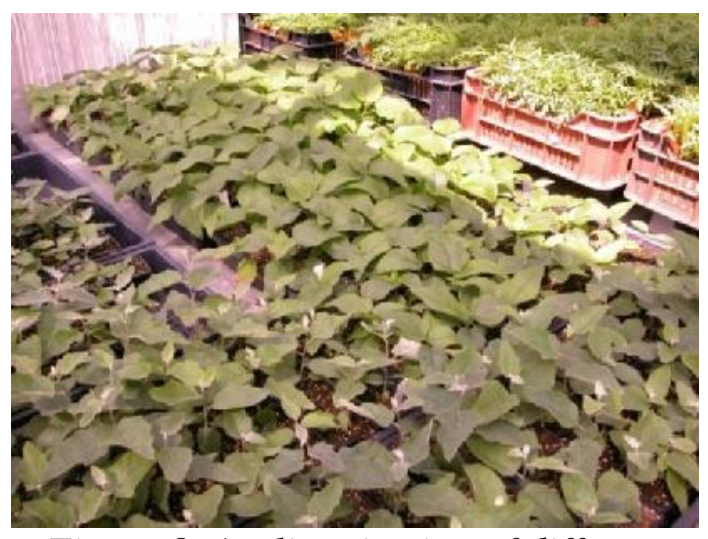

Figure 8. Acclimatization of different poplar clones in the greenhouse

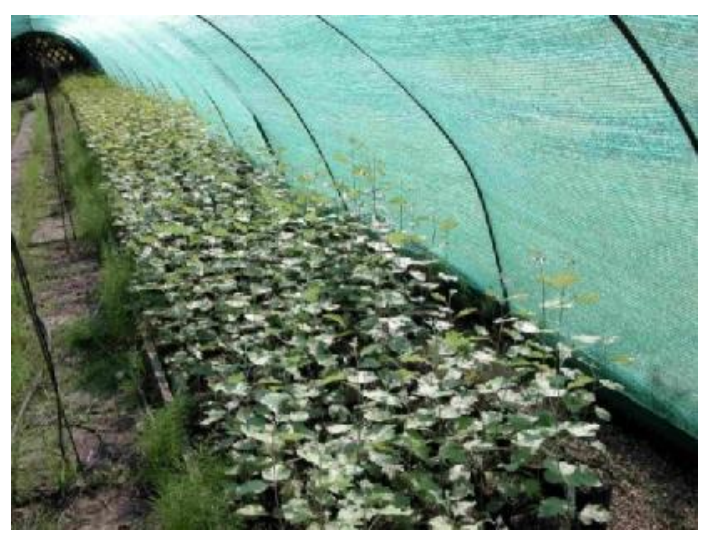

Figure 9. Growth of the white poplars in the nursery garden 
Plantlets acclimatized in the mentioned period in the first growing season grow to the size fit for grafting in August-September in the case of rootstocks, or for reforestation in OctoberNovember in case of forest-trees (Figure 10, 11, 12).

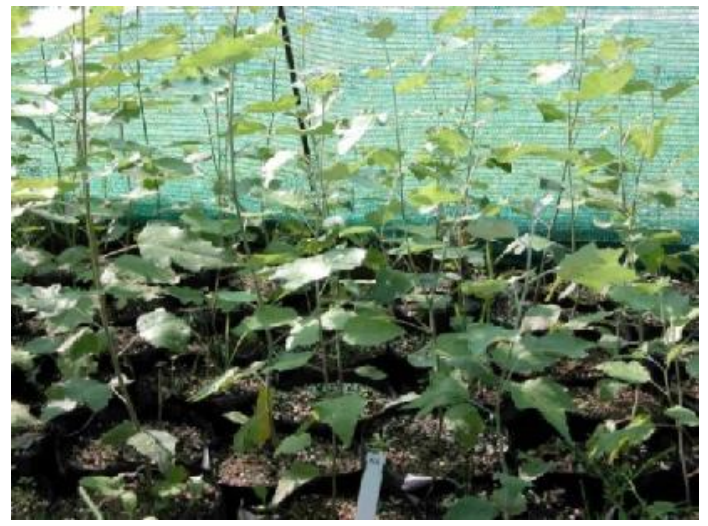

Figure 10. Micropropagated H-325 Leuce poplar clone in the nursery garden

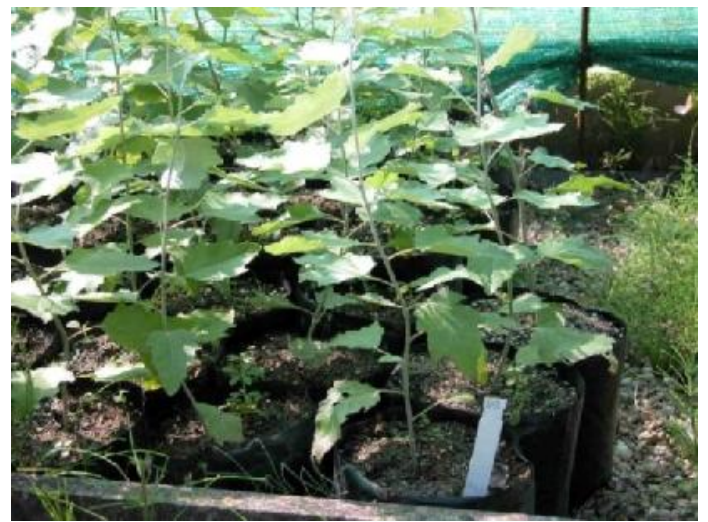

Figure 11. Growth of the $\mathrm{H}-384$ clone in the nursery

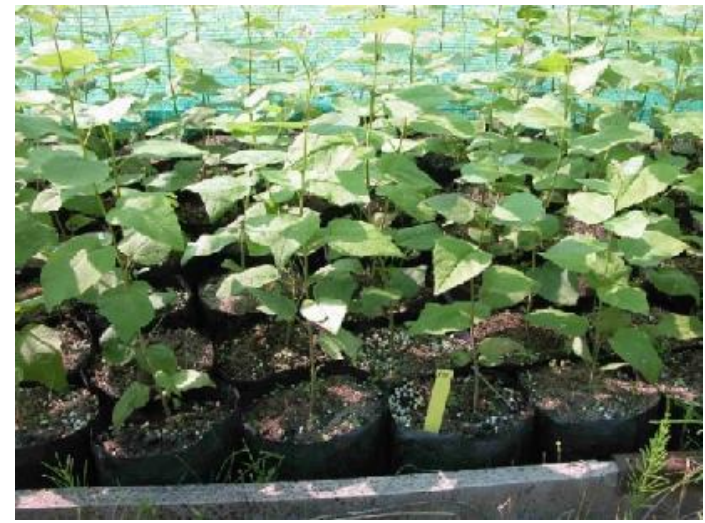

Figure 12. H-337 white poplar clone in the nursery

Hot summer and dark winter periods are not fit for acclimatization. Tree plantlets, acclimatized in autumn are difficult to keep during the winter period, so it is not suggested.

\section{RESULTS}

The evaluations have proved that the clones $P$. alba $\times P$. grandidentata $\mathrm{H}-337$ and $\mathrm{H}-384$ are the most suitable for poplar growing under unfavourable ecological factors, while

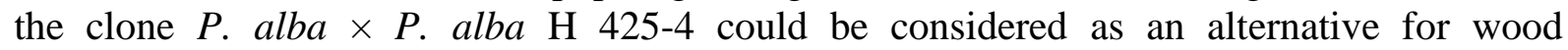
production. The abovementioned promising clones may also be planted in roadside plantations and parks because of their decorative value.

Table 1 shows the most important stand structure parameters of the Leuce-poplar clones at the age of 8 (Kecskemét 40A). Based on the data concerning the growth in height, clones $H-337$ and $H-384$ provided the best results. They surpassed the control by $51 \%$ and $22 \%$ respectively. Regarding the growth in DBH (diameter at breast height) the abovementioned clones surpassed the control by $30 \%$ and $25 \%$; the tendency was also the same with mean tree volume values. The effect of differences in DBH on the mean tree volumes seems to be very considerable (an additional 102\% and 49\% for the above-mentioned clones). Where the stem quality index is concerned, the succession from best to worst is: $\mathrm{H}-337, \mathrm{H}-384, \mathrm{H} \mathrm{425-4,H} \mathrm{H}-325$ and the control. According to the significance test at $P=5 \%$ level, significant differences 
were found in height $\left(S D_{5 \%}=2.07 \mathrm{~m}\right)$, in $\mathrm{DBH}\left(\mathrm{SD}_{5 \%}=2.11 \mathrm{~cm}\right)$ and in the mean tree volume values $\left(S D_{5 \%}=21.2 \mathrm{dm}^{3}\right)$ (Table 2$)$.

Table 1. Some yield data and stem qualification of Leuce-poplar clones at age of 8 years (Kecskemét 40A, 2011)

\begin{tabular}{|c|c|c|c|c|c|c|c|}
\hline \multirow{2}{*}{$\begin{array}{l}\text { Name } \\
\text { of clone }\end{array}$} & \multicolumn{2}{|c|}{ Mean height } & \multicolumn{2}{|c|}{$\begin{array}{l}\text { Mean diameter } \\
\text { at breast height }\end{array}$} & \multicolumn{2}{|c|}{ Mean tree volume } & \multirow{2}{*}{$\begin{array}{l}\text { Stem quality } \\
\text { index } \\
(1-4)\end{array}$} \\
\hline & (m) & $\%$ & $(\mathrm{~cm})$ & $\%$ & $\left(\mathrm{dm}^{3}\right)$ & $\%$ & \\
\hline H-325 & 8.05 & 111 & 7.40 & 102 & 25.8 & 102 & 2.14 \\
\hline $\boldsymbol{H}-337$ & $10.95 b$ & 151 & $9.44 b$ & 130 & $51.3 b$ & 202 & $1.33 b$ \\
\hline $\mathrm{H}-384$ & 8.84 & 122 & 9.08 & 125 & 37.9 & 149 & $1.61 b$ \\
\hline H 425-4 & 7.66 & 106 & 7.82 & 108 & 26.6 & 105 & 1.91 \\
\hline Control & $7.24 a$ & 100 & $7.26 a$ & 100 & $25.3 a$ & 100 & $2.28 a$ \\
\hline SD $_{5 \%}$ & 2.07 & & 2.11 & & 21.2 & & 0.52 \\
\hline
\end{tabular}

Between the values marked by different letters significant differences were found at $P=5 \%$ level.

Table 2. ANOVA values according to the investigated parameters.

\begin{tabular}{|c|c|c|c|c|}
\hline \multicolumn{5}{|c|}{ Height } \\
\hline & $S S$ & $D F$ & $M S$ & $F$ \\
\hline Total & 50.93 & 20 & & \\
\hline Replication & 3.43 & 2 & & \\
\hline Treatment & 30.82 & 6 & 5.1366 & \\
\hline Error & 16.68 & 12 & 1.39 & 3.69 \\
\hline \multicolumn{5}{|c|}{$S D_{5 \%}=2.07$} \\
\hline \multicolumn{5}{|c|}{$\mathrm{DBH}$ (diameter at breast height) } \\
\hline & $S S$ & $D F$ & $M S$ & $F$ \\
\hline Total & 32.21 & 20 & & \\
\hline Replication & 2.32 & 2 & & \\
\hline Treatment & 12.48 & 6 & 2.08 & \\
\hline Error & 17.41 & 12 & 1.4308 & 1.43 \\
\hline \multicolumn{5}{|c|}{$S D_{5 \%}=2.11$} \\
\hline \multicolumn{5}{|c|}{ Mean tree volume } \\
\hline & $S S$ & $D F$ & $M S$ & $F$ \\
\hline Total & 0.003774 & 20 & & \\
\hline Replication & 0.000307 & 2 & & \\
\hline Treatment & 0.001761 & 6 & 0.00029 & \\
\hline Error & 0.001706 & 12 & 0.000142167 & 2.06 \\
\hline \multicolumn{5}{|c|}{$S D_{5 \%}=21.2$} \\
\hline \multicolumn{5}{|c|}{ Stem quality } \\
\hline & $S S$ & $D F$ & $M S$ & $F$ \\
\hline Total & 3.270000 & 20 & & \\
\hline Replication & 0.200000 & 2 & & \\
\hline Treatment & 1.890000 & 6 & 0.3150 & \\
\hline Error & 1.180000 & 12 & 0.0983 & 3.20 \\
\hline \multicolumn{5}{|c|}{$S D_{5 \%}=0.52$} \\
\hline
\end{tabular}


The collected data were analysed using the STATISTICA 8.0 (data analysis software system -StatSoft, Inc. 2008) programme including correlations and regression analysis.

The annual ring evaluation analyses show that selection surplus can also be detected under marginal site conditions. According to the average annual ring width (growth in diameter at breast height), clone H-384 surpassed the control by $52.7 \%$ while clone H-337 surpassed it by $46.2 \%$ (Figure 13).

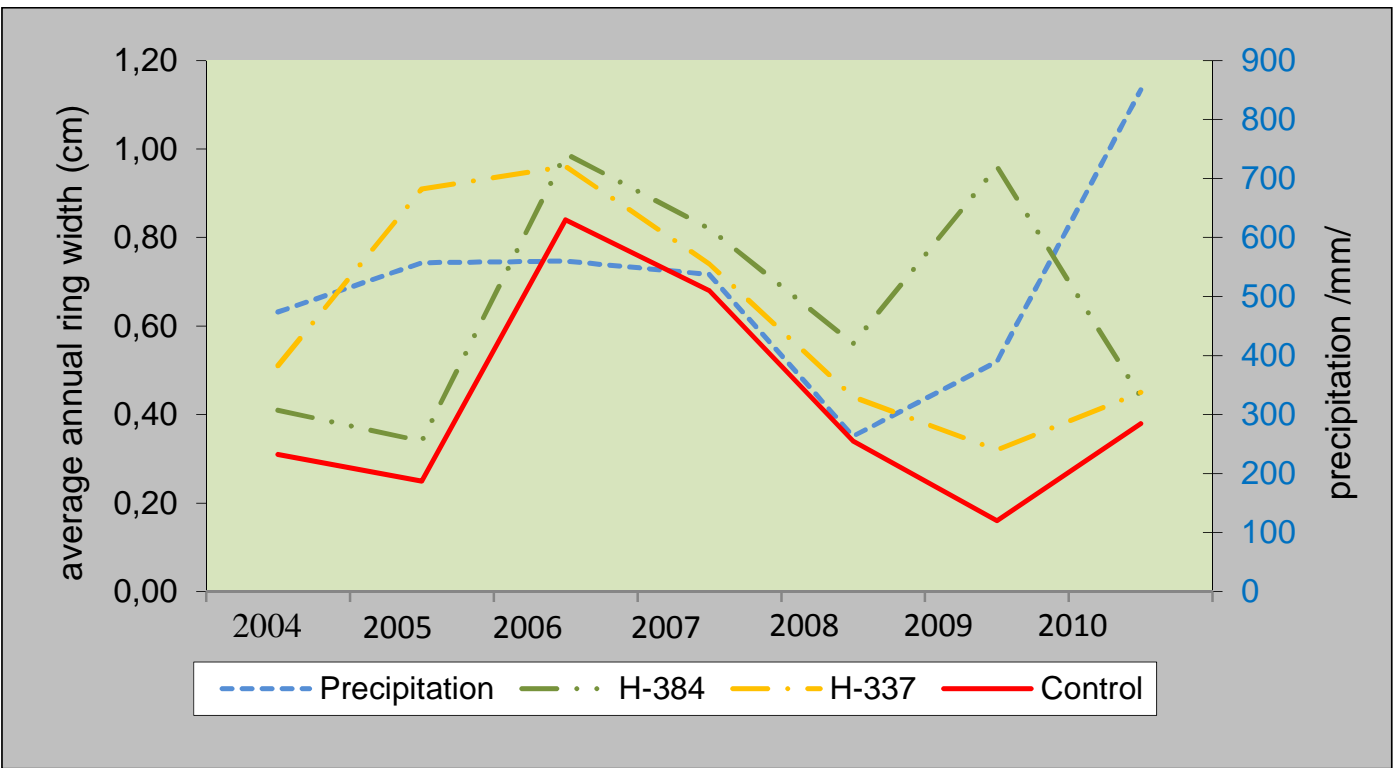

Figure 13. Annual ring analysis of the 2 most promising Leuce-poplar clones at the age of 7 (Kecskemét 40A, 2010)

We have done discriminant analysis considering the DBH (diameter at breast height), height, rate of growth, stem quality, and health condition as quantitative variables - according to the different clones - as observation groups. Figure 14 shows the ordination diagram based on canonical discriminant functions of the variety comparison clone trial.

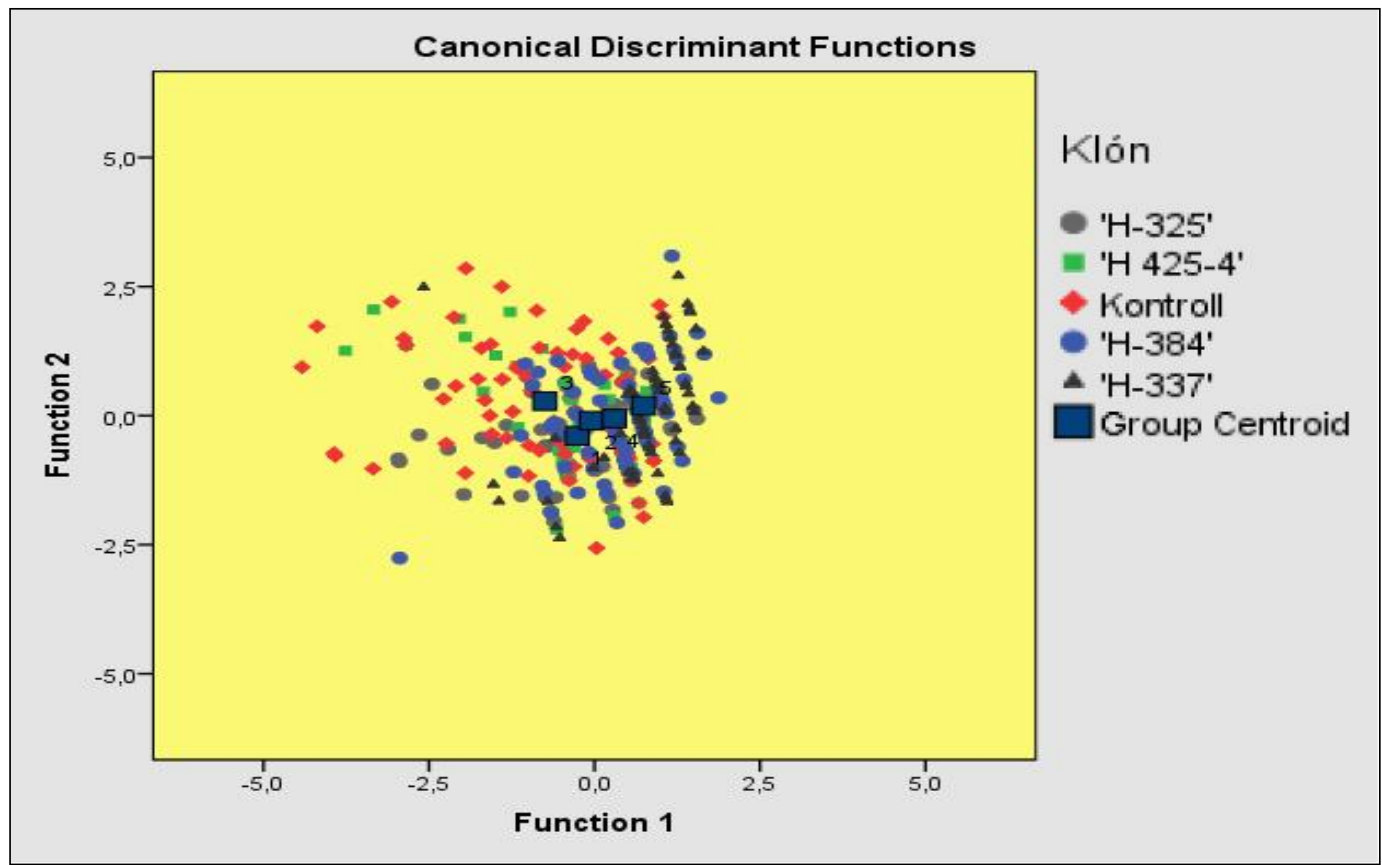

Figure 14. The common ordination diagram of the 5 groups (clones)

on the basis of the investigated characteristics 
In the course of the discriminant analysis it can be said that if the number of groups are more than 2 - as in this case - the discrimination of cases (variables) belonging to the single groups (clones) can be done with the help of so-called canonical variables.

Figure 14 indicates - though not clearly - that the groups separate from each other considering the first function (horizontal axis). The figure also shows that the control (commercial) white poplar specimens show the highest deviation according to the investigated characteristics compared to the other clones.

\section{DISCUSSION}

The H-384 and H-337 clones presented the most homogeneous distribution. These results also prove the excellent stem, form, yield properties, health condition, and the outstanding rate of growth of these 2 promising Leuce-poplar clones (Keser 2013).

In spite all of the efforts to reduce the cost of the micropropagation, using micropropagated plants for reforestation seems to exorbitantly expensive given present economic circumstances. Today a micropropagated plant costs 2 EUR, while the price of a commercial seedling is much lower (cca. 0.1 EUR). In Hungary and also in other countries (Haapala et al. 2004) mother plantations are established from micropropagated plants and from there trees for forestation are propagated year by year using conventional vegetative propagation methods, usually by cuttings (Lubrano 1992, Confalonieri et al. 2003).

Among the forest species, poplars belong to a well-known group and can be used as a model tree for other species (Taylor 2002). The production of clones that grow quickly in shorter periods of time, are adaptable to different sites like poor, polluted soil or drought conditions, and can yield more wood is currently ongoing through the application of biotechnological methods that are based on micropropagation (Lubrano 1992, Giri et al. 2004, Doty 2008, Chen - Polle 2010). Experiments on the production of genetically modified resistant clones against fungal and lepidopteran infections using Agrobacterium mediated transformation methods are improving (Zhang et al. 2005). The important role of poplars among the energy tree species must be stressed (Polle - Douglas 2010, Sanningrahi et al. 2010).

\section{CONCLUSIONS}

The early evaluation demonstrated in the paper showed that the micropropagated clones $\mathrm{H}$ 337 and H-384 seem to be suitable for poplar growing under unfavourable site conditions, while clone $\mathrm{H} 425-4$ could be considered as an alternative for wood production. The experiments have also demonstrated that micropropagated plants can be successfully transplanted into soil, hardened, and grown in the field. Micropropagated trees have been exhibiting normal growth and appearance since they were planted. Hungary has a great deal of experience growing white poplars. A selected clone that has a really high growth capacity, as is demonstrated in the present publication, should be used for reforestation or ornamental purposes despite the higher cost.

\section{ACKNOWLEDGEMENTS: SUPPORT OF THE Ministry OF Agriculture AND RURAL DEVELOPMENT (PROJECT NUMBER: 9 - FVM/K00557/1/2004) IS DEEPLY ACKNOWLEDGED.}




\section{REFERENCES}

AHUJA, M.R. (1983): Somatic cell differentiation and rapid clonal propagation of aspen. Silvae Genetica 32: 131-135.

AHUJA, M.R. (1984): A commercially feasible micropropagation method for aspen. Silvae Genetica 33: $174-176$.

Altman, A. (2003): From plant tissue culture to biotechnology: scientific revolutions, abiotic stress tolerance, and forestry. In vitro Cellular and Developmental Biology-Plant 39: 75-84. 1079/IVP2002379 [Cross Ref]

BAROCKA, K.H. - BAUS, M. - LONTKE, E. - SieVERT, F. (1985): Tissue culture as a tool for in vitro mass-propagation of aspen. Zur Pflanzenzühtung 94: 340-343.

Chalupa, V. (1974): Control of root and shoot formation and production of trees from poplar callus. Biologia Plantarum 16: 316-320.

ChEn, S. - Polle, A. (2010): Salinity tolerance of Populus. Plant Biology 12: 317-333.

CHRISTIE, C. B. (1978): Rapid propagation of aspen and silver poplar using tissue culture techniques. Proceeding of International Plant Propagators Society 28: 255-260.

Chun, Y.W. - HALL, R.B. - STEPHENS, L.C. (1986): Influences of medium consistency and shoot density on in vitro shoot proliferation of Populus alba $\times P$. grandidentata. Plant Cell Tissue Organ Culture 5: 179-185.

ColEmAN, G.D. - ERNST, S.G. (1990): Axillary shot proliferation and growth of Populus deltoides shoot cultures. Plant Cell Reports 9: 165-167.

CONFAlonieri, M. - BALESTRAZZI, A. - BisofFi, S. - CARBOnERA, D. (2003): In vitro culture and genetic engineering of Populus spp.: synergy for forest tree improvement. Plant Cell Tissue and Organ Culture 72: 109-138.

DOTY, S.L. (2008): Enchancing phytoremediation through the use of transgenics and endophytes. New Phytologist 179: 318-333.

Douglas, G. (1982): Protoplast isolation from totipotent cell-cultures of Populus hybrid TT32. In: Fujiwara A. (ed.): Plant Tissue Culture 1982, Proceeding of 5th International Congress on Plant Tissue and Cell Culture. Tokio. 605-606.

GAUTHERET, R.J. (1934): Culture du tissu cambial. Comptes Rendus de l'Académie des sciences (Paris) 198: 2195-2196.

Giri, C.C. - Shyamkumar, B. - Anjaneyulu, C. (2004): Progress in tissue culture, genetic transformation and application of biotechnology to trees: an overview. Trees 18: 115-135.

HaApala, T. - PAKKanen, A. - PulKkinen, P. (2004): Variation in survival and growth of cuttings in two clonal propagation methods for hybrid aspen (Populus tremula $\times$ P. tremuloides). Forest Ecology and Management 193: 345-354.

HÄGGMAN, H. - SUTELA, S. - WelANDER, M. (2007): Micropropagation of Betula pendula Roth including genetically modified material. In: Jain, S.M. - Häggman, H. (eds.): Protocols for Micropropagation of Woody Trees and Fruits. Springer Netherlands, Dordrecht. 153-162.

Iordan-Costache, M. - LOWE, K.C. - DAVEY, M.R. - POWER, J.B. (1995): Improved micropropagation of Populus spp. by pluronic F-68. Plant Growth Regulation 17 (39): 233-239.

KANG, B. - OSBURN, L. - KoPSELL, D. - TUSKAN, G.A. - Cheng, Z.M. (2009): Micropropagation of Populus trichocarpa 'Nisqually-1': the genotype deriving the Populus reference genome. Plant Cell Tissue and Organ Culture 99: 251-257.

KESER , Zs. (2013): A nemesítés szerepe a homoki Leuce-nyárasok termesztés-fejlesztésében [Role of the breeding in growing-improvement of the Leuce-poplar stands growing under sandy soil conditions] Doktori (PhD) értekezés. [(PhD]. Debreceni Egyetem. [University of Debrecen]. 144 P. (in Hungarian).

Leplé, J.C. - Brasileiro, A.C.M. - Michel, M.F. - Delmotte, F. - JouAnin, L. (1992): Transgenic poplars: expression of chimeric genes using four different constructs. Plant Cell Reports 11: 137-141.

LLOYD, G. - MCCOWN, B. (1980): Commercially feasible micropropagation of mountain laurel, Kalmia latifolia, by use of shoot tip culture. Proceeding of International Plant Propagators Society 30: 42-427. 
LUBRANO, L. (1992): Micropropagation of poplars (Populus spp.). In: Bajaj, Y.P. S. (ed.): Biotechnology in Agriculture and Forestry 18, High-Tech and Micropropagation II. Springer, Berlin. 151-178.

MAHESHWARI, P. - KovAlCHUK, I. (2011): Efficient shoot regeneration from internodal explants of Populus angustifolia, Populus balsamifera and Populus deltoids. New Biotechnology 28: 778-787.

MATHES, M.C. (1964): The in vitro formation of plantlets from isolated aspen tissues. Phyton 21: $137-141$.

MCCOWn, B.H. - MCCABE, D.E. - RuSSEL, D.R. - ROBINSON, D.J. - BARTON, K.A. - RAFFA, K.F. (1991): Stable transformation of Populus and incorporation of pest resistance by electric discharge particle acceleration. Plant Cell Reports 9: 590-594.

Murashige, T. - Skoog, F. (1962): A revised medium for rapid growth and bioassay with tobacco tissue cultures. Physiology Plantarum 15: 473-497.

Nishiguchi, M. - YoshidA, K. - Mohri, T. - IgasaKa, T. - Shinora, K. (2006): An improved transformation system for Lombardy poplar (Populus nigra var. italica). Journal of Forestry Research 11: 175-180.

Nö̈L, N. - LePlé, J-C. - Pilate, G. (2002): Optimization of in vitro micropropagation and regeneration for Populus $\times$ interamericana and Populus $\times$ euramericana hybrids ( $P$. deltoides, $P$. trichocarpa, and P. nigra) Plant Cell Reports 20: 1150-1155.

NOH, E.U. - MiNOCHA, S.C. (1986): High efficiency shoot regeneration from callus of quaking aspen (Populus tremuloides Michx.). Plant Cell Reports 5: 464-467.

Phan, T.C. - Jorgensen, J. - Jouve, L. - Haismann, J.F. - Polle, A. - Teichmann, T. (2004): Micropropagation of Populus euphratica Olivier. Belgian Journal of Botany 137: 175-180.

Polle, A. - Douglas, C. (2010): The molecular physiology of poplars: paving the way for knowledge based biomass production. Plant Biology 12: 239-241.

RAHMAN, M.H. - RAJORA, O.P. (2001): Microsatellite DNA somaclonal variation in micropropagated trembling aspen (Populus tremuloides) Plant Cell Reports 20: 531-536.

RÉDEI, K. - BALLA, I. (2007): Vegetatív szaporítás. [Vegetative propagation] In: Rédei, K (ed.): Homoki fehérnyárasok termesztés-fejlesztése. [Improvement of white poplar stands on sandy soils] Agroinform Publishers, Budapest. 18-23. (in Hungarian)

SANNIGRAHI, P. - RAgAusKaS, A.J. - TUSKAN, G.A. (2010): Poplar as a feedstock for biofuels: a review of compositional characteristics. Biofuels, Bioproducts and Biorefining 4: 209-226.

SAVKA, M.S. - SKIRVIN, R.M. - JOKELA, J.J. - DAWSON, J.O. (1985): Culture of ovules containing immature embryos of eastern cottonwood in vitro. at 5th Central Hardwood Forest Conference, Apr. 15-17, 1985, University of Illinois, Urbana, IL. 234-238.

SON, S.H. - HALL, R.B. (1990): Plant regeneration capacity of callus derived from leaf, stem, and root segments of Populus alba $\times$ P. grandidentata Michx.. Plant Cell Reports 9: 344-347.

Song, J. - LU, S. - Chen, Z-Z. - Lourenco, R. - ChiAnG, V.L. (2006): Genetic transformation of Populus trichocarpa genotype Nisqually - 1: A functional genomic tool for woody plants. Plant and Cell Physiology 47 (11): 1582-1589.

TAYLOR, G. (2002): Populus: Arabidopsis for forestry. Do we need a model tree? Annals of Botany 90: 681-689.

ThaKUR, A.K. - SARAswat, A. - SRivastaVA, D.K. (2012): In vitro plant regeneration through direct organogenesis in Populus deltoides clone G48 from petiole explants. Journal of Plant Biochemistry and Biotechnology 21: 23-29.

WANN, S.R. - WYCKOFF, G.W. - WYCKOFF, J.L. (1988): A tissue culture solution to a forestry problem - the propagation of a tetraploid European aspen. Tree Planters' Notes 39 (3): 28-30.

WiNTON, L.L. (1968): Plantlet formation from aspen tissue culture. Science 160: 1234-1235.

WinTON, L.L. (1970): Shoot and tree production from aspen tissue cultures. American Journal of Botany 57: 904-909.

WINTON, L.L. (1971): Tissue culture propagation of European aspen. Forestry Science 17: 348-350.

WHITEHEAD, H.C.M. - GILES, K.L. (1977): Rapid propagation of poplars by tissue culture methods. New Zeland Journal of Forestry Science 7: 40-43.

WOLTER, K.E. (1968): Root and shoot initiation in aspen callus cultures. Science 219: 509-510. 
YAdAV, R. - Arora, P. - Kumar, D. - Katyal, D. - Dilbahi, N. - Chaudhury, A. (2009): High frequency direct plant regeneration from leaf, internode, and root segments of Eastern Cottonwood (Populus deltoids) Plant Biotechnology Report 3: 175-182.

ZHANG, T. - WANG, C. - HU, X. (2000): Tissue culture studies on triploids of Chinese white poplar. $21^{\text {st }}$ Session: International Poplar Commission (IPC 2000), 177.

ZHANG, Q. - ZHANG, Z.Y. - LIN, S.Z. - LIN Y.Z. (2005): Resistance of transgenic hybrid triploids in Populus tomentosa Carr. against 3 species of lepidopterans following two winter dormancies conferred by high level expression of cowpea tripsin inhibitor gene. Silvae Genetica 54 (3): 108-116. 